\title{
Development of Mathematic Learning Set Based on Pedagogical Content Knowledge to Improve Mathematics Problem Solving Ability
}

\author{
Ibut Priono Leksono ${ }^{1 *}$, Sri Rahmawati Fitriatien ${ }^{2}$ \\ ${ }^{1,2}$ Universitas PGRI Adi Buana Surabaya \\ *ibutpriono@gmail.com
}

Received: December 2020; Accepted: December 2020; Published: January 2021

\begin{abstract}
The mathematical problems that used in this research include linear programming problems that are solved with the integer programming method. The aim in this research to product mathematic learning that include implementation plans and woksheets based on pedagogical content knowledge in order to improve mathematical problem solving ability. This research use development research used in this research uses four stages starting with define, then continue with design stage, next the develop stage, and the last stage is disseminate stage. The research subjects used in this study were students of the 2016 class mathematics education program at the Universitas PGRI Adi Buana Surabaya. The results of validation for the result of learning tools show that the pedagogical content knowledge with $4 D$ method are suitable to used with very good categories. Meanwhile, the trial results show that the pedagogical content knowledge learning tools produced are practical and effective. This is able to support an achievement of research object that is able to improve the ability of students to solve math problems for linear programe case by using integer programming method. Keywords: pedagogical content knowledge, problem solving, math problem, integer programming.
\end{abstract}

How to Cite: Leksono, I. P. \& Fitriatien, S. R. (2020). Development of Mathematic Learning Set Based on Pedagogical Content Knowledge to Improve Mathematics Problem Solving Ability. Journal of Medives: Journal of Mathematics Education IKIP Veteran Semarang, 5(1), 159-170. 


\section{PENDAHULUAN}

Penelitian ini dilatarbelakangi oleh kondisi mahasiswa Program Studi Pendidikan Matematika Universitas PGRI Adi Buana Surabaya sebagai calon guru matematika yang kemampun penyelesaian masalah matematika untuk kasus program linier dengan penyelesaian menggunakan metode programa bilangan bulat tergolong masih kurang. Mata kuliah operasional riset (Fitriatien \& Mutianingsih, 2020) ini meliputi program linier dengan penyelesaian sederhana yaitu menggunakan metode grafik, metode simpleks dan dualitas simpleks, model transportasi, metode penugasan, programa bilangan bulat hingga menggunakan metode penyelesaian analisis jaringan.

Pemilihan metode programa bilangan bulat pada penelitian ini sebagai fokus penyelesaian masalah program linier yang diberikan karena berdasarkan pengalaman dan hasil mahasiswa dalam mengerjakan dan memberikan solusi atau jawaban untuk kasus program linier bertolak belakang dengan hasil yang diperoleh untuk penyelesaian menggunakan grafik. Basis penyelesaian programa bilangan bulat merupakan kelanjutan dari penyelesaian program linier (Fitriatien, 2016) menggunakan metode grafik, hanya saja mahasiswa masih kurang dalam penentuan cabang yang digunakan sebagai dasar proses programa bilangan bulat.

Hal ini dirasa perlu bagi tim peneliti untuk menciptakan atau membuat perangkat pembelajaran yang dapat membantu mahasiswa dalam mengasah kemampuan penyelesaian kasus matematika khusus pada program linier dengan penyelesaian programa bilangan bulat. Selain itu, tim peneliti memandang perlu bahwa perangkat pembelajaran yang dihasilkan harus memuat konten pedagogik yang bisa mengasah kemampuan mahasiswa untuk memiliki kompetensi pedagogis dan pengetahuan konten.

Oleh sebab itu, tim peneliti memilih untuk meciptakan atau membuat perangkat pembelajaran berbasis Pedagogical Content Knowledge (PCK) guna membantu meningkatkan kemampuan pemecahan masalah matematika mahasiswa sebagai calon guru.

PCK merupakan pengetahuan konten pedagogik yang pertama kali dipopulerkan oleh Shulman (Harrington, Driskell, Johnston, Browning, \& Niess, 2019) dengan tiga komponen utama yaitu subject matter content knowledge, pedagogical content knowledge, dan curricular knowledge (Gess-Newsome et al., 2019). Komponen PCK ini merupakan elemen penting yang seharusnya dimiliki oleh guru atau dalam hal penelitian ini adalah mahasiswa sebagai calon guru guna meningkatkan kualitas diri sebagai pengajar.

Berdasarkan hal di atas, selayaknya mahasiswa sebagai calon guru memiliki penguasaan materi yang bagus dan kemampuan mengelola pembelajaran. Oleh sebab itu, PCK sangat penting bagi mahasiswa sebagai calon guru untuk menciptakan proses pembelajaran yang bermakna bagi siswa, khususnya untuk materi program linier yang nantinya diajarkan di sekolah yang didasari materi persamaan linier.

Melalui PCK yang dihadirkan pada perangkat pembelajaran sebagai 
dasar utama bahan yang digunakan oleh calon guru sebelum melaksanakan pembelajaran setidaknya mampu melatih kemampuan internal siswa untuk berpikir, memecahkan suatu masalah (Nissa, 2018), dan mengambil keputusan (Shulman, 2019) dapat dilatihkan sebagai kemampuan kognitif.

Kemampuan kognitif tertinggi dari Gagne (Fitriatien, 2019) digambarkan sebagai suatu strategi kognitif yang berupa analisis, sintesis, dan evaluasi yang dapat dipelajari baik oleh siswa maupun guru atau calon guru. Kemampuan ini dapat dilatih melalui pemberian perangkat pembelajaran berupa rencana pelaksanaan pembelajaran yang digunakan oleh guru sebagai pedoman dalam pelaksanaan pembelajaran, sedangkan lembar kerja siswa sebagai tempat melatih siswa mengasah kemampuan menyelesaikan masalah matematika (Fitriatien, 2020). Pada penelitian ini, pedoman pelaksanaan pembelajaran digunakan oleh peneliti, selanjutnya untuk lembar kerja siswa yang ditransformasi menjadi lembar kerja mahasiswa digunakan oleh mahasiswa Program Studi Pendidikan Matematika Universitas PGRI Adi Buana Surabaya sebagai calon guru sekaligus sebagai subjek pada penelitian ini.

Konsep PCK dituangkan dalam perangkat pembelajaran berupa rencana pelaksanaan pembelajaran dan lembar kerja mahasiswa memberikan pengertian bahwa untuk mengajar matematika di sekolah tidak cukup hanya memahami konten materi saja (knowing science) (Ayoubi, El Takach, \& Rawas, 2017) tetapi diperlukan adanya kemampuan cara mengajar (how to teach) (Iserbyt,
Ward, \& Li, 2017). Hal ini sejalan dengan hasil penelitian yang dilakukan oleh Mega Wulandari dan Ade Iriani yang menyatakan bahwa modul yang berbasis PCK yang telah dikembangkan memperoleh penilaian cukup baik dari ahli, kategori sangat baik dari calon pengguna (Wulandari \& Iriani, 2018). Sementara itu, hasil penelitian (Rafi \& Sabrina, 2019) menunjukkan bahwa capaian rata-rata uji kompetensi guru pada bidang studi matematika yang mampu mengembangkan profesionalitas guru matematika melalui aktivitas pembelajaran dengan workshop pada materi geometri transformasi di sekolah menengah atas.

Keberhasilan implementasi PCK juga terlihat pada hasil belajar siswa berbasis inkuiri terbimbing mampu meningkatkan hasil pembelajaran siswa (Laoli \& Bunawan, 2018). Selain itu, melalui PCK pula mampu melatih mahasiswa mengembangkan bahan ajar tematik SD sesuai dengan kompetensi inti dan kompetensi dasar yang telah ditentukan (Saifudin \& Sukma, 2019).

Pada penelitian yang dilakukan oleh tim peneliti ini, peneliti mengaitkan materi-materi yang berkaitan dengan kasus sehari-hari yang berkaitan dengan program linier sebagai wujud pembelajaran dalam kerangka perangkat pembelajaran berbasis PCK.

\section{METODE PENELITIAN}

Penelitian pengembangan yang diterapkan pada penelitian ini menggunakan model pengembangan 4D. Model pengembangan ini (Sugiyono, 2018) meliputi empat tahapan pelaksanaan pengembangan yaitu membuat 
definisi, membuat rancangan, melakukan pengembangan, dan melakukan desiminiasi. Perangkat pembelajaran yang dikembangkan pada penelitian ini meliputi rencana pelaksanaan pembelajaran dan lembar kerja mahasiswa.

Pengembangan produk ini dilakukan mulai bulan Mei 2019, kemudian dilakukan uji terbatas pada November 2019, dan uji coba lapangan pada Januari 2020. Uji coba pengembangan perangkat pembelajaran ini dilakukan pada mahasiswa Program Studi Pendidikan Matematika Universitas PGRI Adi Buana Surabaya.

Subjek uji coba terbatas dilaksanakan pada mahasiswa Program Studi Pendidikan Matematika angkatan 2016 sebanyak 12 mahasiswa. Mahasiswa angkatan 2016 terdiri dari 3 kelas, yaitu kelas A, kelas B, dan kelas C. Untuk uji coba lapangan dipilih Kelas B yang terdiri dari mahasiswa heterogen dan Kelas C yang terdiri dari kelompok mahasiswa kelas malam. Dosen team teaching yang terdiri dari dua orang bertindak sebagai guru yang melaksanakan pembelajaran di kelas menggunakan perangkat pembelajaran yang dikembangkan.

Untuk tahapan penelitian pengembangan ini, diawali dengan melakukan analisis pada kemampuan mahasiswa menyelesaikan masalah matematika, analisis materi perkuliahan untuk mata kuliah operasional riset yang memuat di dalamnya materi program linier dengan penyelesaian menggunakan metode programa bilangan bulat, analisis tugas, analisis capaian mata kuliah, analisis penggunaan media perkuliahan, analisis pada desain produk, kemudian dilakukan uji ahli dan praktisi, dilaksanakannya uji coba terbatas, dan yang terakhir analisis uji coba lapangan.

Rancangan perangkat pembelajaran yang telah dibuat oleh tim peneliti, dilakukan revisi menjadi produk perbaikan. Rancangan perangkat pembelajaran ini diuji coba terbatas untuk memperoleh data keterbacaan perangkat dan pelaksanaan pembelajaran. Kemudian dilakukan perbaikan kembali sesuai masukan ahli yang selanjutnya dilakukan uji coba lapangan menggunakan produk perbaikan yang kedua. Setelah memperoleh keseluruhan data, peneliti melanjutkan pada tahapan analisis data. Pada hasil analisis data ini, apabila produk belum memperoleh penilaian praktis dan efektif, peneliti melakukan perbaikan perangkat pembelajaran kembali hingga mencapai kelayakan dan memenuhi penilaian produk yang valid, praktis dan efektif.

Instrumen penelitian ini menggunakan lembar validasi dan lembar lembar observasi keterlaksanaan pembelajaran serta tes kemampuan pemecahan masalah matematika. Untuk kevalidan perangkat pembelajaran (Widoyoko, 2012) yang dikembangkan tim peneliti terdiri dari 5 skala penilaian yaitu (5) dengan penilaian sangat baik; (4) penialaian baik; (3) dengan penilaian cukup; (2) dengan penilaian kurang baik; dan (1) dengan penilaian tidak baik. Kemudian dari hasil penilaian tersebut disimpulkan bahwa perangkat pembelajaran yang dibuat layak untuk digunakan, atau layak digunakan dengan perbaikan, atai tidak layak digunakan.

Untuk data kuantitatif kemudian dikonversi menjadi data kualitatif untuk 
perolehan skala. Sistem konversi yang peneliti lakukan berdasarkan konversi dari Widoyoko dan disajikan pada Tabel 1 (Widoyoko, 2012).

Tabel 1. Kriteria Penilaian Tingkat Validasi Instrumen

\begin{tabular}{clc}
\hline Nilai & \multicolumn{1}{c}{ Interval Skor } & Kategori \\
\hline A & $X>\bar{X}_{i}+1.8 s b_{i}$ & Sangat baik \\
B & $\bar{X}_{i}+0.6 s b_{i}<X$ & Baik \\
& $\leq \bar{X}_{i}+1.8 \mathrm{sb}_{\mathrm{i}}$ & \\
$\mathrm{C}$ & $\bar{X}_{i}-0.6 s b_{i}<X$ & Cukup \\
& $\leq \bar{X}_{i}+0.6 \mathrm{sb}_{\mathrm{i}}$ & \\
$\mathrm{D}$ & $\bar{X}_{i}-1.8 s b_{i}<X$ & Kurang \\
& $\leq \bar{X}_{i}-0.6 \mathrm{sb}_{\mathrm{i}}$ & \\
$\mathrm{E}$ & $X \leq \bar{X}_{i}-1.8 s b_{i}$ & Sangat \\
& & kurang \\
\hline
\end{tabular}

Keterangan:

$\bar{X}_{i}=$ rerata skor ideal

$\mathrm{sb}_{\mathrm{i}}=$ simpangan baku ideal

$X=$ skor aktual

Kemudian untuk lembar observasi keterlaksanaan pembelajaran digunakan untuk memperoleh data penilaian mahasiswa selama pembelajaran di kelas menggunakan perangkat pembelajaran yang dikembangkan tim peneliti. Selanjutnya, keefektifan dari perangkat pembelajaran yang dikembangkan dilihat dari tes kemampuan penyelesaian masalah matematika yang diberikan kepada mahasiswa.

Perangkat pembelajaran yang dikembangkan oleh tim peneliti dikatakan valid untuk digunakan setidaknya memperoleh penilaian pada kategori baik pada masing-masing penilaian (Retnawati, 2017). Kemudian untuk kepraktisan dalam penggunaannya (Hilman \& Retnawati, 2015) dilihat dari pengetahuan dan kemampuan pemecahan masalah matematika mahasiswa. Sementara untuk keefektifan (Jailani \& Retnawati, 2016) perangkat pembelajar- an ditinjau dari hasil tes kompetensi mahasiswa berdasarkan capaian pembelajaran mata kuliah untuk materi program linier dengan penyelesaian menggunakan programa bilangan bulat.

\section{HASIL DAN PEMBAHASAN}

Perangkat pembelajaran yang dikembangkan berdasarkan aspek kevalidan, kepraktisan, dan keefektifan yang dibuat oleh tim peneliti dibatasi pada materi program linier dengan menggunakan penyelesaiaan programa bilangan bulat. Hasil penelitian pengembangan ini dibagi dalam bentuk analisis hasil validasi, kemudian analisis hasil uji coba terbatas, dan terakhir adalah analisis hasil uji coba lapangan.

Untuk hasil validasi yang dilakukan oleh ahli yang terdiri dari 3 ahli dari Universitas Negeri Surabaya dan 3 praktisi yaitu guru SMPN 12 Surabaya. Perolehan penilaian validitas perangkat pembelajaran disajikan pada Tabel 2.

Tabel 2. Kategori Validitas Penilaian Perangkat Pembelajaran

\begin{tabular}{ccl}
\hline \multicolumn{2}{c}{ Jenjang Skor Rata-rata } & \\
$\begin{array}{c}\text { Rencana } \\
\text { Pelaksanaan } \\
\text { Pembelajaran }\end{array}$ & $\begin{array}{c}\text { Lembar Kerja } \\
\text { Mahasiswa }\end{array}$ & \\
\hline$X>150,5$ & $X>79,6$ & Sangat baik \\
$122,6<X \leq 150,5$ & $63,6<X \leq 79,6$ & Baik \\
$92,7<X \leq 122,6$ & $48,7<X \leq 63,6$ & Cukup \\
$64,7<X \leq 92,7$ & $34,7<X \leq 48,7$ & Kurang baik \\
$X \leq 64,7$ & $X \leq 34,7$ & Tidak baik \\
\hline
\end{tabular}

Sementara itu untuk penilaian yang diberikan oleh keenam ahli ini dirangkum pada Tabel 3 untuk perolehan skor atau nilai aktual untuk produk yang dikembangkan oleh tim peneliti. 
Tabel 3. Hasil Validasi Ahli

\begin{tabular}{lcl}
\hline \multicolumn{1}{c}{$\begin{array}{c}\text { Perangkat } \\
\text { Pembelajaran }\end{array}$} & $\begin{array}{c}\text { Rata- } \\
\text { Rata } \\
\text { Skor }\end{array}$ & Kategori \\
\hline $\begin{array}{l}\text { Rencana pelaksanaan } \\
\text { pembelajaran }\end{array}$ & 134,8 & Baik \\
$\begin{array}{l}\text { Lembar kerja } \\
\text { mahasiswa }\end{array}$ & 83,1 & $\begin{array}{l}\text { Sangat } \\
\text { baik }\end{array}$ \\
\hline
\end{tabular}

Pada Tabel 3 menyatakan perolehan validasi produk perangkat pembelajaran yang telah dikembangkan oleh tim peneliti memperoleh penilaian dari tim ahli bahwa produk yang dikembangkan layak digunakan setelah dilakukan perbaikan berdasarkan masukan tim ahli yang selanjutnya dapat dilakukan uji coba.

Setelah produk telah memenuhi kriteria valid dengan kategori minimal pada kondisi baik untuk rencana pelaksanaan pembelajaran dan kategori sangat baik untuk lembar kerja mahasiswa, maka tim peneliti melaksanakan uji coba terbatas untuk produk yang dikembangkan.

Uji coba terbatas dilakukan pada 12 mahasiswa Program Studi Pendidikan Matematika Universitas PGRI Adi Buana Surabaya angkatan 2016 yang telah mengampu mata kuliah operasional. Mahasiswa diberikan lembat kerja mahasiswa yang memuat soal yang berkaitan dengan program linier akan yang penyelesaiannya menggunakan programa bilangan bulat.

Uji coba terbatas yang dilakukan ini menghasilkan analisis data kepraktisan yang meliputi kepraktisan dari sisi dosen yang diperankan oleh team teaching mata kuliah operasional riset dan mahasiswa selaku pengguna perangkat pembelajaran yang setidaknya dapat memberikan penilaian kelayakan penggunaan perangkat pembelajaran yang dikembangkan oleh tim peneliti. Pada pelaksanaan uji terbatas, diperoleh data keterlaksanaan pembelajaran dengan mengimplementasikan perangkat pembelajaran yang dikembangkan.

Data hasil penilaian dari mahasiswa untuk variabel kepraktisan dalam menggunakan perangkat pembelajaran yang telah dikembangkan tim peneliti diperoleh setelah mahasiswa selesai proses pembelajarannya dengan memberikan penilaian untuk perangkat pembelajaran berupa rencana pelaksanaan pembelajaran yang dapat ditelaah selama proses team teaching melakukan kegiatan mengajar berlangsung. Sementara itu untuk lembar kerja mahasiswa dilakukan penilaian setelah proses pembelajaran selesai dan mahasiswa mengerjakan soal latihan yang diberikan oleh team teaching berupa soal program linier yang membutuhkan penyelesaian menggunakan programa bilangan bulat.

Untuk penilaian kepraktisan perangkat pembelajaran yang dilakukan oleh mahasiswa dan team teaching yang berperan sebagai dosen pengajar pada kelas penelitian dilakukan analisis baik analisis kualitatif maupun kuantitatif dengan kriteria sangat setuju (5); setuju (4); ragu-ragu (3); tidak setuju (2); dan sangat tidak setuju (1). Tanggapan berupa skor tersebut selanjutnya dilakukan konversi menjadi data kualitatif yang disajikan pada Tabel 4 dan Tabel 5.

Sementara itu untuk hasil rekapitulasi penilaian mahasiswa untuk variabel kepraktisan dari perangkat pembelajaran yang meliputi rencana 
pelaksanaan pembelajaran dan lembar kerja mahasiswa disajikan pada Tabel 6.

Tabel 4. Kategori Kepraktisan Perangkat Pembelajaran berdasarkan Penilaian Mahasiswa

\begin{tabular}{ccl}
\hline \multicolumn{2}{c}{ Jenjang Skor Rata-rata } & Kategori \\
\cline { 1 - 2 } $\begin{array}{c}\text { Lembar Kerja } \\
\text { Mahasiswa }\end{array}$ & $\begin{array}{c}\text { Proses } \\
\text { Pembelajaran }\end{array}$ & \\
\hline$X>37,3$ & $X>25,8$ & Sangat baik \\
$30,1<X \leq 37,3$ & $20,6<X \leq 25,8$ & Baik \\
$23,7<X \leq 30,1$ & $15,8<X \leq 20,6$ & Cukup \\
$16,8<X \leq 23,7$ & $10,6<X \leq 15,8$ & Kurang baik \\
$X \leq 16,8$ & $X \leq 10,6$ & Tidak baik \\
\hline
\end{tabular}

Tabel 5. Kategori Penilaian Team Teaching terhadap Kepraktisan Perangkat Pembelajaran

\begin{tabular}{ccl}
\cline { 1 - 2 } \multicolumn{2}{c}{ Jenjang Skor Rata-Rata } & \\
$\begin{array}{c}\text { Rencana } \\
\text { Pelaksanaan } \\
\text { Pembelajaran }\end{array}$ & $\begin{array}{c}\text { Lembar Kerja } \\
\text { Mahasiswa }\end{array}$ & Kategori \\
\hline$X>43$ & $X>29,6$ & Sangat baik \\
$35<X \leq 43$ & $23,5<X \leq 29,6$ & Baik \\
$27<X \leq 35$ & $18,8<X \leq 23,5$ & Cukup \\
$19<X \leq 27$ & $12,4<X \leq 18,8$ & Kurang baik \\
$X \leq 19$ & $X \leq 12,4$ & Tidak baik \\
\hline
\end{tabular}

Tabel 6. Rekapitulasi Penilaian Mahasiswa terhadap Kepraktisan Perangkat Pembelajaran

\begin{tabular}{lcl}
\multicolumn{3}{c}{ pada Uji Terbatas } \\
\hline \multicolumn{1}{c}{$\begin{array}{c}\text { Perangkat } \\
\text { Pembelajaran }\end{array}$} & $\begin{array}{l}\text { Rata- } \\
\text { Rata } \\
\text { Skor }\end{array}$ & Kategori \\
\hline $\begin{array}{l}\text { Lembar kerja } \\
\text { mahasiswa }\end{array}$ & 36,2 & Baik \\
$\begin{array}{l}\text { Proses } \\
\text { pembelajaran }\end{array}$ & 22,1 & Baik \\
\hline
\end{tabular}

Hasil penilaian mahasiswa terhadap perangkat pembelajaran yang dikembangkan oleh tim peneliti untuk penilaian kepraktisan perangkat pembelajaran berupa lembar kerja mahasiswa dan pelaksanaan proses pembelajaran yang berlangsung berada pada kategori baik. Hal ini menunjukkan bahwa produk pengembangan dan komponen pendukungnya memenuhi praktis menurut peniliaian mahasiswa.

Sementara itu, pada uji terbatas ini untuk hasil rekapitulasi penilaian dari team teaching yang bertindak sebagai dosen pada kelas penelitian ini untuk variabel kepraktisan dari perangkat pembelajaran disajikan pada Tabel 7 .

Tabel 7. Rekapitulasi Penilaian Team Teaching terhadap Kepraktisan Perangkat Pembelajaran pada Uji Terbatas

\begin{tabular}{lcl}
\hline \multicolumn{1}{c}{$\begin{array}{c}\text { Perangkat } \\
\text { Pembelajaran }\end{array}$} & $\begin{array}{c}\text { Rata-Rata } \\
\text { Skor }\end{array}$ & Kategori \\
\hline $\begin{array}{l}\text { Rencana pelaksanaan } \\
\text { pembelajaran }\end{array}$ & 45,0 & $\begin{array}{l}\text { Sangat } \\
\text { Baik }\end{array}$ \\
$\begin{array}{l}\text { Lembar kerja } \\
\text { mahasiswa }\end{array}$ & 25,0 & Baik \\
\hline
\end{tabular}

Hasil penilaian team teaching pada perangkat pembelajaran memperoleh penilaian dengan kategori sangat baik. Artinya, untuk pengembangan perangkat pembelajaran yang dikembangkan memenuhi kategori praktis.

Setelah melaksanakan uji coba terbatas, tahapan selanjutnya adalah tim peneliti melakukan uji coba lapangan. Hasil perbaikan dari produk perangkat pembelajaran pada tahapan uji coba sebelumnya, oleh tim peneliti telah dilakukan perbaikan sesuai saran dan masukan untuk digunakan pada tahapan uji coba lapangan. Uji coba lapangan dilakukan pada mahasiswa Program Studi Pendidikan Matematika angkatan 2016 kelas B dan kelas C. Pemilihan kelas ini berdasarkan kondisi mahasiswa yang ada di kelas B merupakan mahasiswa heterogen sementara untuk kelas $\mathrm{C}$ adalah kelas malam yang sebagian besar mahasiswa pekerja.

Pada uji coba lapangan ini, tim peneliti melakukan analisis data untuk kepraktisan dan keefektifan penggunaan perangkat pembelajaran. Sama halnya pada uji coba terbatas, untuk analisis kepraktisan tim peneliti melakukan 
analisis penilaian dari mahasiswa dan team teaching yang bertindak sebagai dosen pengajar pada kelas penelitian.

Berikut disajikan Tabel 8 yaitu hasil rekapitulasi penilaian mahasiswa terhadap kepraktisan perangkat pembelajaran pada uji lapangan.

Tabel 8. Rekapitulasi Uji Lapangan Penilaian Mahasiswa terhadap Kepraktisan Perangkat Pembelajaran

\begin{tabular}{lccl}
\hline \multirow{2}{*}{ Aspek } & \multicolumn{2}{c}{ Rata-rata } & \\
& \multicolumn{2}{c}{ Skor } & Kategori \\
\cline { 2 - 3 } & $\mathbf{2 0 1 6}$ & $\mathbf{2 0 1 6}$ & \\
& B & C & \\
\hline $\begin{array}{l}\text { Lembar kerja } \\
\text { mahasiswa }\end{array}$ & 38,1 & 38,0 & Sangat \\
Proses & & & Baik \\
pembelajaran & 30,0 & 27,7 & Sangat \\
& & & Baik \\
\hline
\end{tabular}

Hasil penilaian mahasiswa pada uji lapangan untuk penilaian kepraktisan perangkat pembelajaran berupa lembar kerja mahasiswa dan komponen pendukungnya termasuk proses pelaksanaan pembelajaran berada dalam kategori sangat baik. Artinya, dari hasil ini menunjukkan terdapat peningkatan penilaian mahasiswa jika dibandingkan ketika tim peneliti melakukan uji coba terbatas yang kategori penilaian mahasiswa pada kategori baik. Hasil pada uji coba lapangan ini menunjukkan bahwa perangkat pembelajaran yang dikembangkan oleh tim peneliti memenuhi kriteria praktis dengan kategori sangat baik menurut penilaian mahasiswa.

Untuk penilaian perangkat pembelajaran yang dilakukan oleh team teaching pada uji coba lapangan kepraktisan perangkat pembelajaran yang dikembangkan oleh tim peneliti disajikan pada Tabel 9.
Tabel 9. Rekapitulasi Uji Lapangan Kepraktisan Penilaian Team Teaching

\begin{tabular}{lcl}
\hline \multicolumn{1}{c}{$\begin{array}{c}\text { Perangkat } \\
\text { Pembelajaran }\end{array}$} & $\begin{array}{c}\text { Rata-Rata } \\
\text { Skor }\end{array}$ & Kategori \\
\hline $\begin{array}{l}\text { Rencana } \\
\text { pelaksanaan } \\
\text { pembelajaran }\end{array}$ & 46,1 & $\begin{array}{l}\text { Sangat } \\
\text { Baik }\end{array}$ \\
$\begin{array}{l}\text { Lembar kerja } \\
\text { mahasiswa }\end{array}$ & 32,3 & $\begin{array}{l}\text { Sangat } \\
\text { Baik }\end{array}$ \\
\hline
\end{tabular}

Hasil penilaian team teaching pada uji coba lapangan menunjukkan peningkatan kategori pada perangkat pembelajaran berupa lembar kerja mahasiswa. Semula untuk penilaian team teaching pada uji coba terbatas berada pada kategori baik, selanjutnya pada uji coba lapangan memberikan penilaian kategori sangat baik. Secara keseluruhan, penilaian team teaching pada uji coba lapangan untuk produk pembelajaran yang dikembangkan oleh tim peneliti berada pada penilaian sangat baik. Hal ini menunjukkan bahwa pengembangan perangkat pembelajaran memenuhi kriteria praktis dengan penilaian sangat baik.

Untuk keterlaksanaan pembelajaran pada uji coba lapangan ini dilakukan sebanyak empat kali dengan hasil rekapitulasi penilaian capaian keberhasilan keterlaksaan pembelajaran disajikan pada Tabel 10.

Tabel 10. Rekapitulasi Pelaksanaan Pembelajaran pada Uji Lapangan

\begin{tabular}{cc}
\hline Kelas & $\begin{array}{c}\text { Rata-Rata Capaian } \\
\text { Pelakasanaan }(\boldsymbol{\%})\end{array}$ \\
\hline $2016 \mathrm{~B}$ & 92,7 \\
$2016 \mathrm{C}$ & 81,4 \\
\hline
\end{tabular}

Berdasarkan Tabel 10. keberhasilan keterlaksanaan pembelajaran rata-rata di atas $80 \%$. Hal ini 
menunjukkan bahwa perangkat pembelajaran yang dikembangkan peneliti mampu membantu capaian pembelajaran untuk materi program linier dengan penyelesaian menggunakan metode programa bilangan bulat. Secara garis besar, hubungan antara ketersediaan perangkat pembelajaran yang minimal memproleh penilaian kategori baik dari ahli mampu memberikan dampak yang positif pada ketercapaian pelaksanaan pembelajaran. Hal ini juga sejalan dengan penelitian yang dilakukan oleh Rusnilawati menyatakan bahwa perangkat pembelajaran yang berada pada kategori penilaian sangat baik mampu membantu ketercapaian langkah-langkah pembelajaran di kelas dengan menggunakan perangkat pembelajaran yang baik (Rusnilawati, 2016). Sementara hasil penelitian yang yang lain menunjukkan bahwa keterlaksanaan pembelajaran rata-rata $91,43 \%$ melalui pengembangan perangkat pembelajaran berupa LKS dengan pendekatan matematika realistik (Indraningtias \& Wijaya, 2017).

Sementara itu untuk analisis keefektifan yang dilakukan mahasiswa untuk perangkat pembelajaran diperoleh dari hasil tes pemecahan masalah yang dilakukan mahasiswa. Soal tes berupa soal program linier yang membutuhkan penyelesaian menggunakan metode programa bilangan bulat. Untuk analisis hasil tes digunakan untuk mengetahui kriteria keefektifan perangkat pembelajaran yang dikembangkan oleh tim peneliti. Komponen yang dinilai pada tes ini adalah tingkat kemampuan mahasiswa dalam memecahkan masalah matematika.
Skor pemecahan masalah menggunakan instrumen tes kemampuan masalah yang telah divalidasi oleh satu ahli yaitu dosen jurusan matematika Institut Teknologi Sepuluh Nopember dengan bidang ilmu riset operasi. Kemampuan mahasiswa dalam melaksanakan langkah pemecahan masalah mulai pemahaman mahasiswa terhadap masalah yang disajikan, kemudian membuat rancangan penyelesaian dari masalahnya, selanjutnya mengerjakan atau melaksanakan rancangan solusi, dan yang terakhir adalah memeriksa kembali penyelesaian soal menunjukkan adanya perbaikan. Tes yang diberikan kepada mahasiswa sebanyak dua kali pada kelas 2016 B dan 2016 C.

Secara ringkas hasil tes kemampuan pemecahan masalah matematika pada mahasiswa Program Studi Pendidikan Matematika Universitas PGRI Adi Buana Surabaya angkatan 2016 kelas B dan C disajikan pada Tabel 11 dan Tabel 12.

Tabel 11. Ketuntasan Nilai Tes Pemecahan

Masalah

\begin{tabular}{lccc}
\hline \multirow{2}{*}{ Kelas } & \multicolumn{2}{c}{ Tes Pemecahan Maslah (\%) } \\
\cline { 2 - 4 } & Tes I & Tes II & $\begin{array}{c}\text { Rata-rata } \\
\text { Nilai Tes }\end{array}$ \\
\hline 2016 B & 84,6 & 88,1 & 86,35 \\
2016 C & 82,3 & 84,8 & 83,55 \\
2016 B \& C & 83,9 & 86,4 & 85,15 \\
\hline
\end{tabular}

Tabel 12. Rekapitulasi Nilai Tes Pemecahan

\begin{tabular}{lcccc}
\multicolumn{4}{c}{ Kelas } & \multicolumn{2}{c}{ Tes I } & \multicolumn{2}{c}{ Tes II } \\
\cline { 2 - 5 } & Awal & Akhir & Awal & Akhir \\
\hline 2016 B & 71,6 & 93,2 & 72,7 & 95,1 \\
2016 C & 57,7 & 82,7 & 63,8 & 86,3 \\
2016 B \& C & 66,2 & 90,8 & 70,4 & 92,8 \\
\hline
\end{tabular}


Persentase ketuntasan tes pemecahan masalah untuk kelas 2016 B pada awal tes I sebesar $84,6 \%$ dan mengalami peningkatan pada tes II sebesar $88,1 \%$. Sedangkan untuk kelas $2016 \mathrm{C}$ pada tes I sebesar $82,3 \%$ dan mengalami peningkatan pada tes II sebesar $84,8 \%$. Sementara untuk gabungan antara mahasiswa kelas 2016 B \& C pada tes I sebesar $83,9 \%$ dan mengalami peningkatan pada tes II sebesar $86,4 \%$.

Berdasarkan hasil rekapitulasi nilai rata-rata tes pemecahan masalah untuk kelas 2016 B, 2016 C, dan 2016 B $\& \mathrm{C}$ dengan peningkatan nilai pada pre test dan post test.

Hasil temuan tersebut sesuai dengan penelitian yang dilakukan oleh Yustianingsih, dkk bahwa alat dan perangkat pembelajaran yang tepat disajikan untuk siswa mampu membantu kemampuan siswa dalam menyelesaikan masalah matematika sebasar $75 \%$ atau lebih (Yustianingsih, Syarifuddin, \& Yerizon, 2017). Selain itu, penelitian hasil M.Amir, dkk yang mengembangan perangkat pembelajaran berbasis masalah konstekstual mampu menghasilkan keterlaksanaan pembelajaran pada kategori baik (Amir \& Kusuma W, 2018).

\section{PENUTUP}

Perangkat pembelajaran berupa rencana pelaksanaan pembelajaran dan lembar kerja mahasiswa yang dikembangkan mahasiswa berbasis pedagogical content knowledge dikategorikan valid. Melalui perangkat pembelajaran berbasis berbasis pedagogical content knowledge pula mampu meningkatkan kemampuan mahasiswa dalam menyelesaikan masalah matematika khususnya untuk kasus program linier dengan penyelesaian programa bilangan bulat. Hal ini menunjukkan bahwa perangkat pembelajaran berbasis pedagogical content knowledge layak, praktis, dan efektif digunakan sebagai bahan perangkat pembelajaran guna ketercapaian pelaksanaan pembelajaran dengan penilaian kategori baik.

\section{DAFTAR PUSTAKA}

Amir, M. F., \& Kusuma W, M. D. (2018). Pengembangan Perangkat Pembelajaran Berbasis Masalah Kontekstual untuk Meningkatkan Kemampuan Metakognisi Siswa Sekolah Dasar. Journal of Medives: Journal of Mathematics Education IKIP Veteran Semarang. https://doi.org/10.31331/medives. v2i1.538

Ayoubi, Z., El Takach, S., \& Rawas, M. (2017). Improving the Pedagogical Content Knowledge (PCK) among Cycle 3 In-Service Chemistry Teachers Attending the Training Program at the Faculty of Education, Lebanese University. Journal of Education in Science, Environment and Health. https://doi.org/10.21891/jeseh.326 753

Fitriatien, S. R. (2016). Penerapan Metode Polya Pada Soal Cerita Program Linear. Buana Matematika: Jurnal Ilmiah Matematika Dan Pendidikan Matematika. https://doi.org/10.36456/buanamat ematika.v6i2:.613

Fitriatien, S. R. (2019). Analisis Kesalahan Dalam Menyelesaikan 
Soal Cerita Matematika Berdasarkan Newman. JIPMat. https://doi.org/10.26877/jipmat.v4 i1.3550

Fitriatien, S. R. (2020). Evaluasi Kemampuan Pemecahan Masalah Matematika Berdasarkan Gaya Belajar. Jurnal Pendidikan Matematika. https://doi.org/10.36709/jpm.v11i 1.10053

Fitriatien, S. R., \& Mutianingsih, N. (2020). Peningkatan Kemampuan Belajar Mandiri pada Mata Kuliah Operasional Riset melalui Self Regulated Learning. Mosharafa: Jurnal Pendidikan Matematika.

Gess-Newsome, J., Taylor, J. A., Carlson, J., Gardner, A. L., Wilson, C. D., \& Stuhlsatz, M. A. M. (2019). Teacher pedagogical content knowledge, practice, and student achievement $\dagger$. International Journal of Science Education.

https://doi.org/10.1080/09500693. 2016.1265158

Harrington, R. A., Driskell, S. O., Johnston, C. J., Browning, C. A., \& Niess, M. L. (2019). Technological Pedagogical Content Knowledge. In TPACK. https://doi.org/10.4018/978-15225-7918-2.ch016

Hilman, H., \& Retnawati, H. (2015). Pengembangan Perangkat Pembelajaran Matematika SMP Dengan Metode Inkuiri Pada Persamaan dan Pertidaksamaan Linear Satu Variabel. Jurnal Riset Pendidikan Matematika. https://doi.org/10.21831/jrpm.v2i1 .7149

Indraningtias, D. A., \& Wijaya, A. (2017). Pengembangan Perangkat Pembelajaran Berbasis Pendekatan
Matematika Realistik Materi Bangun Ruang Sisi Datar Beorientasi pada Kemampuan Berpikir Kritis Siwa Kelas VIII SMP. Jurnal Pendidikan Matematika.

Iserbyt, P., Ward, P., \& Li, W. (2017). Effects of improved content knowledge on pedagogical content knowledge and student performance in physical education. Physical Education and Sport Pedagogy.

https://doi.org/10.1080/17408989. 2015.1095868

Jailani, J., \& Retnawati, H. (2016). Keefektifan Pemanfaatan Perangkat Pembelajaran Berbasis Masalah untuk Meningkatkan HOTS dan Karakter Siswa. Jurnal Pendidikan Dan Pembelajaran.

Laoli, Y., \& Bunawan, W. (2018). Implementasi Pedagogical Content Knowledge (PCK) Berbasis Inkuiri Terbimbing Terhadap Hasil Belajar Siswa. INPAFI (Inovasi Pembelajaran Fisika). https://doi.org/10.24114/inpafi.v5i 4.9225

Nissa, I. C. (2018). Mengukur Pengetahuan Konten Pedagogik Guru Matematika: Suatu Kajian Literatur. Jurnal Kependidikan: Jurnal Hasil Penelitian Dan Kajian Kepustakaan Di Bidang Pendidikan, Pengajaran Dan Pembelajaran. https://doi.org/ 10.33394/jk.v4i1.902

Rafi, I., \& Sabrina, N. (2019). Pengintegrasian TPACK dalam Pembelajaran Geometri SMA untuk Mengembangkan Profesionalitas Guru Matematika. SJME (Supremum Journal of Mathematics Education). https://doi.org/10.31235/osf.io/v2 
ygb

Retnawati, H. (2017). Validitas dan reliabilitas konstruk skor tes kemampuan calon mahasiswa. Jurnal Ilmu Pendidikan.

Rusnilawati, R. (2016). Pengembangan perangkat pembelajaran matematika bercirikan active knowledge sharing dengan pendekatan saintifik kelas VIII. Jurnal Riset Pendidikan Matematika.

https://doi.org/10.21831/jrpm.v3i2 .10633

Saifudin, M. F., \& Sukma, H. H. (2019). Pedagogical Content Knowledge (PCK) Calon Guru SD Melalui Mata Kuliah Pengembangan dan Praktik Pembelajaran Bahasa dan Sastra SD. Jurnal VARIDIKA. https://doi.org/10.23917/varidika. v30i2.7576

Shulman, L. S. (2019). Those who understand: Knowledge growth in teaching. Profesorado. https://doi.org/10.30827/profesora do.v23i3.11230

Sugiyono. (2018). Metode Peneiltian Kuantitatif, Kualitatif dan R\&D. In Alfabeta Bandung.
Widoyoko, E. P. (2012). Teknik penyusunan instrumen penelitian. Yogyakarta: Pustaka Pelajar.

Wulandari, M. R., \& Iriani, A. (2018). Pengembangan Modul Pelatihan Pedagogical Content Knowledge (PCK) Dalam Meningkatkan Kompetensi Profesional dan Kompetensi Pedagogik Guru Matematika SMP. Kelola: Jurnal Manajemen Pendidikan. https://doi.org/10.24246/j.jk.2018. v5.i2.p177-189

Yustianingsih, R., Syarifuddin, H., \& Yerizon, Y. (2017). Pengembangan Perangkat Pembelajaran Matematika Berbasis Problem Based Learning (PBL) untuk Meningkatkan Kemampuan Pemecahan Masalah Peserta Didik Kelas VIII. JNPM (Jurnal Nasional Pendidikan Matematika). https://doi.org/10.33603/jnpm.v1i 2.563 